by Julie A. Hollis ${ }^{l}$ and Andrew S. Wygralak ${ }^{2}$

\title{
A review of the geology and uranium, gold and iron ore deposits of the Pine Creek Orogen
}

\author{
${ }^{1}$ Geological Survey of Western Australia, 100 Plain St, East Perth, WA 6004, Australia.E-mail: julie.hollis@dmp.wa.gov.au \\ ${ }^{2}$ Northern Territory Geological Survey, PO Box 3000, Darwin, NT 0801, Australia, E-mail: andrew.wygralak@nt.gov.au
}

The Pine Creek Orogen comprises a succession of Paleoproterozoic sedimentary and volcanic rocks, unconformably overlying Neoarchean granitic basement and intruded by Paleoproterozoic mafic rocks and granites. The orogen is subdivided from west to east into the Litchfield Province, Central Domain and Nimbuwah Domain, based on the distinct timing and nature of sedimentation, magmatism and metamorphism. The orogen hosts a wide range of commodities, the most important of which are $U$ and Au. Rifting of Neoarchean basement at 2020 Ma led to deposition of clastic, carbonate, and carbonaceous sedimentary and volcanic rocks in a shallow basin. At 1870 Ma, sedimentation in the Nimbuwah Domain was rapidly followed by burial, I-type granitic magmatism (1867-1860 Ma), compressional tectonism and mid-pressure amphibolite-facies metamorphism (1865-1855 Ma). Major U deposits occur in the Nimbuwah Domain within basal Paleoproterozoic strata, close to tectonised contacts with Neoarchean basement. Metamorphism of the Nimbuwah Domain coincided with sedimentation and volcanism in the Central Domain and Litchfield Province at 1863 Ma. This was followed by extensional high-temperature, low-pressure metamorphism (1855 Ma) and associated felsic and arc-related mafic magmatism (1862-1850 Ma) in the Litchfield Province. At or after this time, greenschist-facies metamorphism and upright folding and shearing occurred at upper crustal levels in the Central Domain, generating structural traps for subsequent Au- and Fe-bearing fluids. Almost all Au occurrences are associated with late to post orogenic, I-type Cullen Supersuite granites (1835-1820 Ma). Shortly thereafter, platform sediments were deposited in braided rivers across the orogen. The strong spatial heterogeneity in the distribution of $U$ and Au suggests that the pre-existing crustal architecture of the orogen was a significant factor controlling their distribution.

\section{Introduction}

The Pine Creek Orogen is exposed over $47,500 \mathrm{~km}^{2}$ on the northern margin of the North Australian Craton. The orogen comprises Neoarchean (2670-2500 Ma) granitic and gneissic basement that is unconformably overlain by a $>4 \mathrm{~km}$ thick succession of Paleoproterozoic clastic, carbonate and carbonaceous sedimentary and volcanic rocks. The orogen hosts over 1000 mineral occurrences, with major commodities including $\mathrm{Au}, \mathrm{U}, \mathrm{Pb}-\mathrm{Zn}$ - $\mathrm{Ag}$, platinum-group elements, $\mathrm{Cu}-\mathrm{Co}-\mathrm{Ni}, \mathrm{Fe}$ ore, $\mathrm{Sn}-\mathrm{Ta}-\mathrm{W}$ and phosphate.

The Pine Creek Orogen is subdivided, from west to east, into the low-pressure amphibolite- to granulite-facies Litchfield Province, greenschist-facies Central Domain, and mid-pressure amphibolitefacies Nimbuwah Domain (Figure 1). Historically, Paleoproterozoic tectonometamorphism in the Pine Creek Orogen was attributed to the 1885-1850 Ma 'Barramundi Orogeny' (Etheridge et al., 1987; Needham et al., 1988; Page and Williams, 1988), but this term has been abandoned because recent studies showed that different parts of the orogen were affected by chronologically distinct events of contrasting character (Carson et al., 2008; Hollis et al., 2009b, 2011; Glass, 2010). Their recognition has had a major influence on understanding the geological context of important mineralising systems.

We present a review of the geological evolution of the Pine Creek Orogen to provide a revised context for understanding the mineralising systems. We discuss three particular commodities $\mathrm{U}, \mathrm{Au}$ and $\mathrm{Fe}$ ore - focusing on deposits visited during a field trip associated with the $34^{\text {th }}$ International Geological Congress.

\section{Geology of the Pine Creek Orogen}

\section{Neoarchean}

Most of the exposed Archean basement to the North Australian Craton occurs within the Pine Creek Orogen. Neoarchean rocks outcrop in the Central and Nimbuwah domains, and probably underlie much of the Pine Creek Orogen. They comprise c. 2670 Ma, 2640 Ma and 2545-2510 Ma granite and gneiss (Williams and Compston, 1983; Cross et al., 2005; Hollis et al., 2009a). No Archean basement has been identified in the Litchfield Province.

\section{Paleoproterozoic}

\section{c. 2020 Ma sedimentation, magmatism and tectonism}

Rifting of Neoarchean basement at c. 2020 Ma resulted in the 


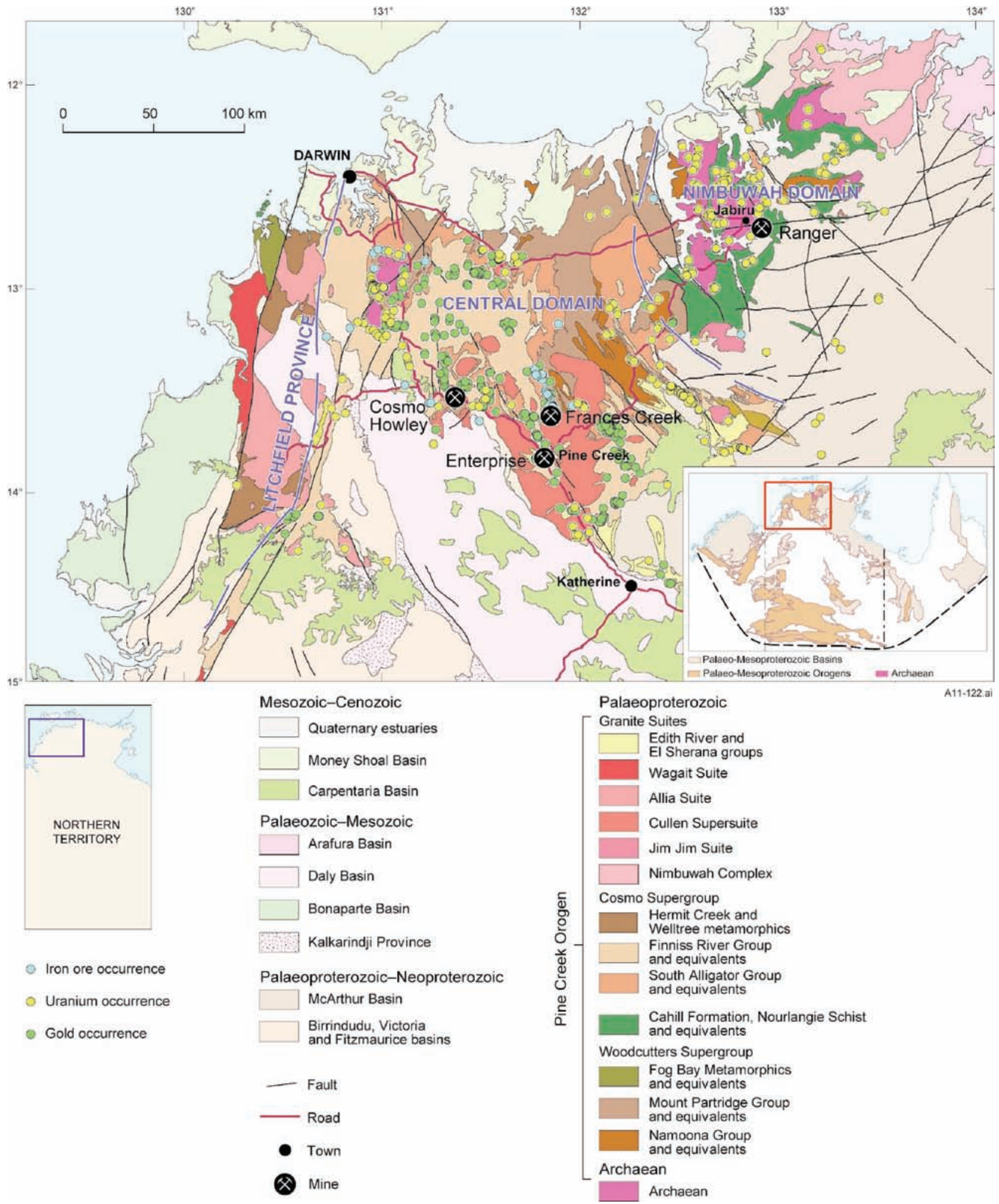

Figure 1 Generalised geology of the Pine Creek Orogen showing the three tectonostratigraphic domains and some of the major mineral deposits. Inset shows location of the Pine Creek Orogen within the North Australia Craton.

deposition of clastic, carbonate and carbonaceous sediments and volcanics of the Woodcutters Supergroup across the Central and Nimbuwah domains. These strata comprise conglomerate, sandstone and siltstone (Crater and Beestons formations), stromatolitic dolostone and magnesite (Celia Dolostone), black pyritic and dolomitic shale, tuff, slate, metagreywacke and dolarenite (Masson
Formation), and basaltic to andesitic lava and agglomerate (Stag Creek Volcanics; Figure 2; Worden et al., 2008a, b). The presence of reduced pelitic and dolomitic rocks, rare pillow structures and interbedded tuffaceous shale in volcanic units indicate a shallow marine depositional environment. Quartzite and metaarkose of the Kakadu Group in the Nimbuwah Domain are probable 


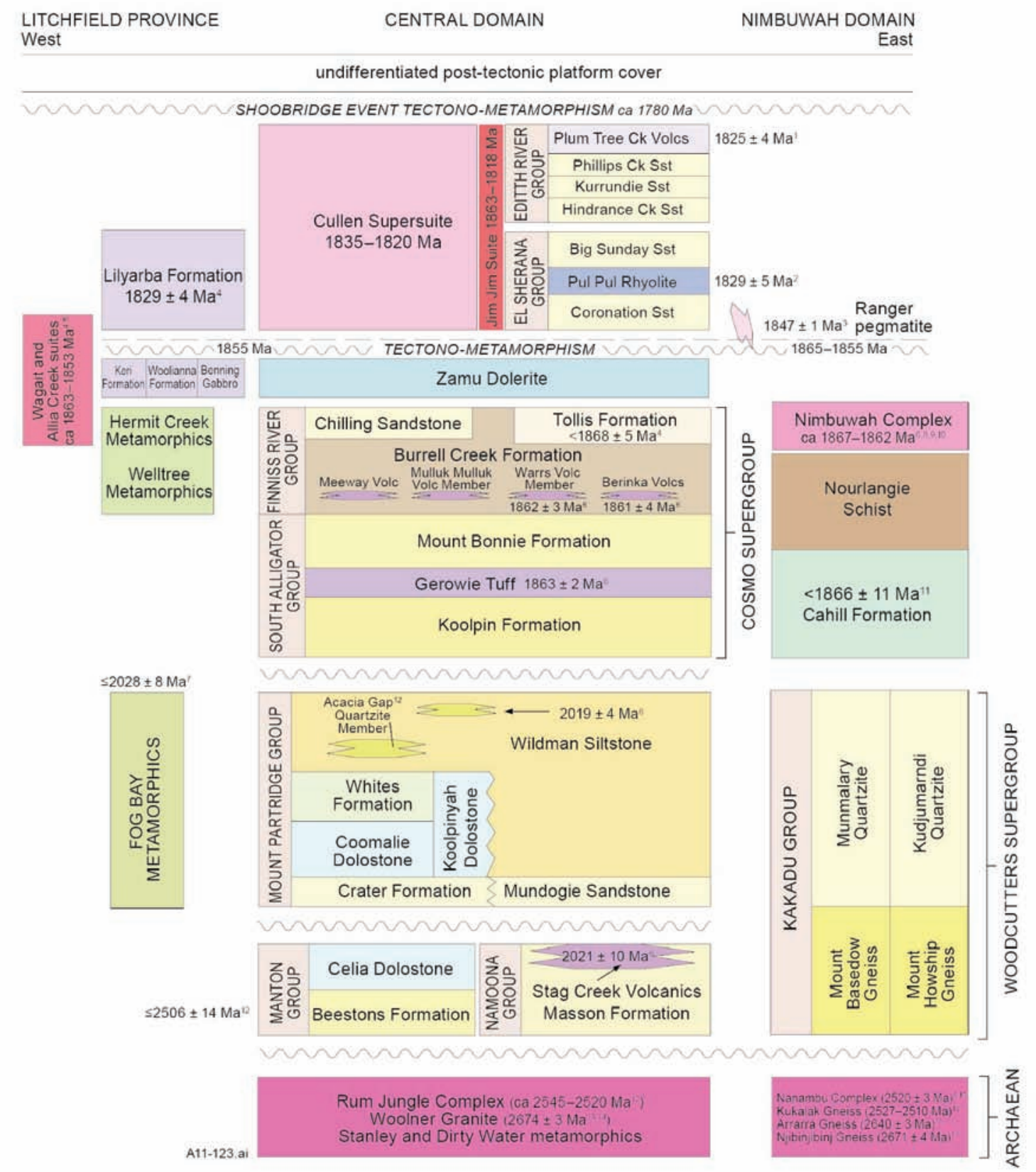

Figure 2 Simplified stratigraphic column of Pine Creek Orogen modified from (Worden et al., 2008b). ${ }^{1}$ Page (1996a), ${ }^{2}$ Jagodzinski (1998), ${ }^{3}$ Annesley et al. (2002), ${ }^{4}$ Worden et al. (2008a), ${ }^{5}$ Page et al. (1985), ${ }^{6}$ Worden et al. (2008b), ${ }^{7}$ Carson et al. (2009), ${ }^{8}$ Carson et al. (2010), ${ }^{9}$ Hollis et al. (2009b), ${ }^{10}$ Page et al. (1980), ${ }^{11}$ Hollis et al. (2011), ${ }^{12}$ Cross et al. (2005), ${ }^{13}$ Glass et al. (2010), ${ }^{14}$ McAndrew et al. (1985), ${ }^{15}$ Hollis et al. (2009a); $\mathrm{Ck}=$ Creek; Sst $=$ Sandstone; Volcs = Volcanics .

higher metamorphic grade equivalents (Figure 2; Worden et al., 2008a).

\section{c. 1870 Ma sedimentation, magmatism and tectonism}

Sedimentation at c. $1870 \mathrm{Ma}$ in an Eastern Trough (Nimbuwah Domain) occurred shortly prior to sedimentation at $1863 \mathrm{Ma}$ in a Central Trough (Litchfield Province/Central Domain); the detritus in the two successions is of distinct ages, indicating different source regions (Hollis et al., 2009b, 2011).

In the Nimbuwah Domain, the Cahill Formation comprises schist (some of it carbonaceous), calc-silicate rock, para-amphibolite, and quartzite, grading upwards into quartzofeldspathic mica schist of the Nourlangie Schist (Figure 2; Needham, 1988). Protoliths to these rocks were metamorphosed at amphibolite facies in the mid crust and cut by W- to NW-vergent thrusts and isoclinal folds at c. 1865-1855 Ma. This occurred during or immediately after the main phase of emplacement of I-type monzogranitic to quartz monzodioritic plutons of the Nimbuwah Complex at 1867-1860 Ma (Worden et al., 2008b; Carson et al., 2010).

In the Central Domain sedimentary and volcanic rocks of the 1863 Ma Cosmo Supergroup were unconformably deposited on the Woodcutters Supergroup coeval with mid-crustal tectonism in the Nimbuwah Domain. The Cosmo Supergroup (Figure 2) comprises iron-rich sedimentary rocks, tuff, carbonate and siliciclastic rocks 
(South Alligator Group), overlain by a thick turbidite succession with interbedded felsic volcanic rocks (Finniss River Group; Needham et al., 1988). The turbidites are dominated by c. 1865 Ma detritus (Worden et al., 2008a, b), possibly derived from an actively uplifted Nimbuwah Domain shedding sediment into an evolving Central Trough. The Cosmo Supergroup experienced greenschist-facies metamorphism associated with tight upright $\mathrm{N}-\mathrm{S}$ folding prior to $\mathrm{c}$. $1835 \mathrm{Ma}$.

Cosmo Supergroup correlatives are known in the Litchfield Province (Hermit Creek and Welltree metamorphics; Figure 2; Pietsch and Edgoose, 1988; Worden et al., 2008a). These were intruded by 1863-1850 Ma S-type granites of the Allia Creek and Wagait suites. In contrast to the Central and Nimbuwah domains, metamorphism in the Litchfield Province at $1855 \mathrm{Ma}$ is characterised by low-pressure, high-temperature assemblages (Carson et al., 2008); coupled with arc-related mafic magmatism (Woolianna Formation; Figure 2), this style of metamorphism is consistent with a back-arc environment (Glass, 2010).

\section{c. 1835-1820 Ma late-orogenic magmatism and tectonism}

In the Central Domain, syn- to late-orogenic granites of the Cullen Supersuite were emplaced at $1835-1820 \mathrm{Ma}$ as a series of plutons termed the Cullen batholith (Figure 1; Worden et al., 2008a). This magmatism was synchronous with the deposition of fluviatile, lacustrine and alluvial fan sedimentary rocks and subaerial volcanic and volcaniclastic rocks unconformably on the South Alligator Group in a fault-bound graben at 1829-1822 Ma (El Sherana and Edith River groups, South Alligator Valley; Figure 2; Needham et al., 1988; Freidmann and Grotzinger, 1994).

\section{$<1818$ Ma sedimentation}

Deposition of braided fluvial sediments of the Katherine River Group at the base of the McArthur Basin started after the $1825 \mathrm{Ma}$ deposition of the Edith River Group and before 1720 Ma granite emplacement (Rawlings and Page, 1999). They were deposited over the Nimbuwah Domain, and at least parts of the Central Domain, and extend far to the southeast. The basal Kombolgie Subgroup comprises conglomerate and quartz sandstone, with mafic volcanic and volcaniclastic intervals in the lower part (Sweet et al., 1999).

\section{Economic geology}

The Pine Creek Orogen is the most fertile part of the North Australian Craton, with over 1,000 mineral occurrences. It contains over $20 \%$ of the world's low-cost U resources, has a known resource of about $9 \mathrm{M} \mathrm{oz}$ of $\mathrm{Au}$, and produced $3.2 \mathrm{M}$ oz of Au between 1870 and 2007. Considerable resources of Ni-Co-Pb-Cu, Pb-Zn-Ag, Pt$\mathrm{Pd}, \mathrm{Sn}-\mathrm{Ta}-\mathrm{W}, \mathrm{Fe}$ ore, magnesite, phosphate and other commodities also exist in this region.

Structurally controlled deposits are predominantly vein type and include $\mathrm{Au}$, base metals, and Sn-bearing veins and Sn-Ta pegmatites. Stratigraphically controlled deposits include stratiform Au and stratabound polymetallic deposits, as well as volcanogenic massive sulfides, U, Fe ore, phosphate and magnesite deposits. The distributions of $\mathrm{U}, \mathrm{Au}$ and $\mathrm{Fe}$ ore mineralisation were largely controlled by large-scale hydrothermal systems, active at distinct stages in the orogenic history. In the following section we provide a brief description of these three mineralisation types (Figure 1).

\section{Uranium mineralisation}

Uranium deposits in the Pine Creek Orogen are grouped into four main types: unconformity-related, vein-type, intrusive-related and surficial deposits (Lally and Bajwah, 2006). Major deposits cluster around the East Alligator (Nimbuwah Domain), South Alligator and Rum Jungle U fields (Central Domain, Figure 1), although the only operating mine is Ranger, located in the East Alligator $U$ field, $260 \mathrm{~km}$ east of Darwin.

Ranger is one of the largest $\mathrm{U}$ mines in the world. The original Ranger 1 orebody, mined from 1980-1994, produced 18 Mt of ore grading $0.3 \% \mathrm{U}_{3} \mathrm{O}_{8}$. Mining at Ranger 3 commenced in 1997 at the rate of $>5,000 \mathrm{t} \mathrm{U}_{3} \mathrm{O}_{8}$ per year. In January 2010, Energy Resources of Australia reported the total resource at Ranger 3 as $127 \mathrm{Mt}$ at $0.09 \%$ $\mathrm{U}_{3} \mathrm{O}_{8}$. Recent drilling has outlined an eastern extension, named Ranger 3 Deeps, which is a target of current exploration. The total endowment (past production plus remaining resource) of Ranger 1 and 3 stands at $130,000 \mathrm{t}$ of metal contained in ore grading $0.24-0.37 \% \mathrm{U}_{3} \mathrm{O}_{8}$ (MODAT, 2011).

The mineralisation is broadly stratabound, being hosted in the carbonaceous lower Cahill Formation, close to the contact with the unconformably underlying Neoarchean Nanambu Complex (Figure 1). Amphibolite-facies metamorphism was associated with NNE- to WNW-trending folds, thrusts and shear zones, cross-cut by easttrending pegmatite veins and gently-dipping NNE-trending mafic dykes, historically interpreted as the Oenpelli Dolerite. Uranium was introduced during late extension after emplacement of the dolerite (Hein, 2002). Fluid-rock interaction during mineralisation produced extensive alteration including chloritisation, sericitisation and hematitisation.

The primary $\mathrm{U}$ minerals are uraninite and pitchblende, with some coffinite and minor brannerite and curite. Free Au occurs in uraninite. Secondary U minerals include saleeite, sklodowskite, torbanite and kasolite.

Existing mineralisation models for the Alligator Rivers Uranium Field differ in (a) the relative importance assigned to unconformities at the Neoarchean basement/Cahill Formation and Cahill Formation/ Kombolgie Subgroup contacts and (b) the inferred source of Ubearing fluids (i.e., basin-derived vs. basement-derived). However, there is increasing consensus that the fluids were basin-sourced and descended from the Kombolgie Subgroup into the Paleoproterozoic basement where mineralisation occurred. Polito et al. (2011) proposed a general model in which the Kombolgie Subgroup was deposited over the Neoarchean and Paleoproterozoic basement and compartmentalised into diagenetic aquifers and aquitards. Diagenetic illite, syn-ore sericite and uraninite formed at $1680 \mathrm{Ma}$, indicating a link between fluid flow in the sandstones and mineralisation (Figure 3 ). This is supported by the similar chemical and isotopic nature of fluid inclusions and diagenetic minerals in the Kombolgie Subgroup and in syn-ore quartz veins (Polito et al., 2005). Hydraulic fracturing in basement-rooted structures during basin formation and fluid flow may have provided a mechanism for formation of uraninite-bearing veins and breccias. Their interaction with reduced lithologies in the basement provided a mechanism for $U$ precipitation. 

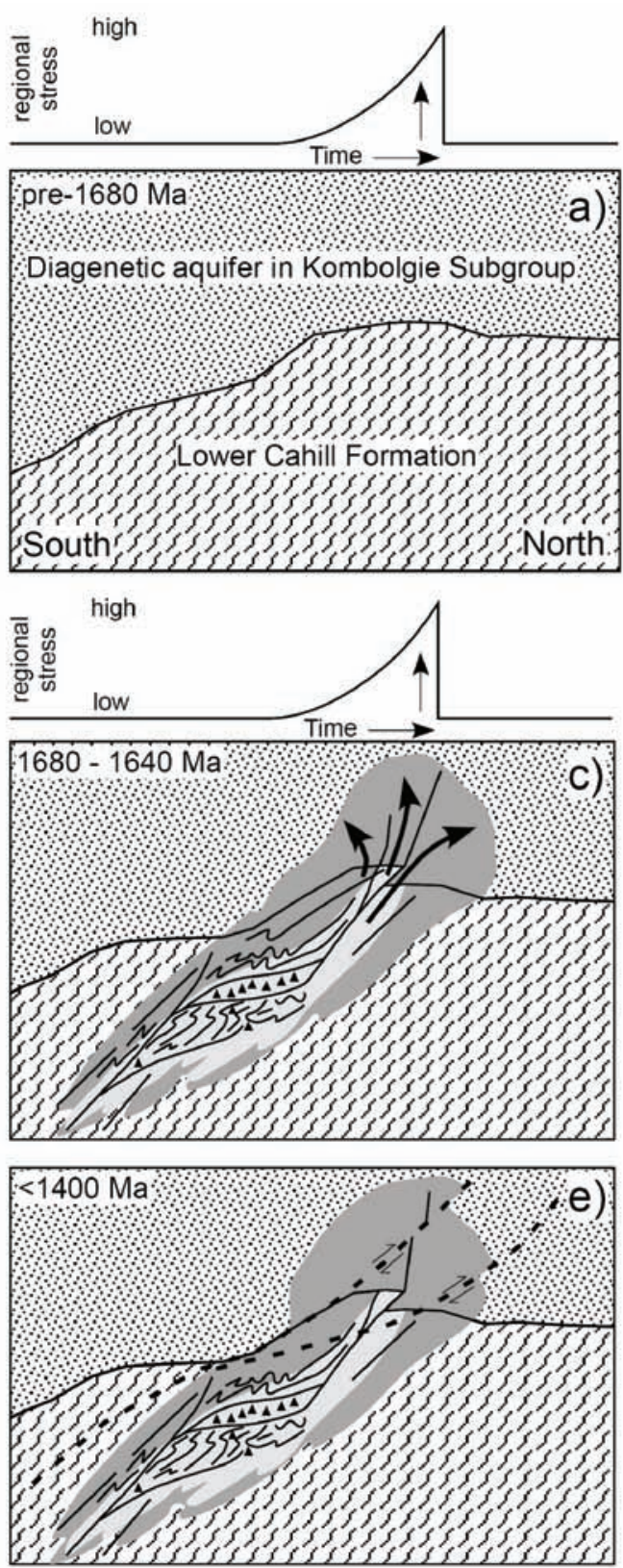
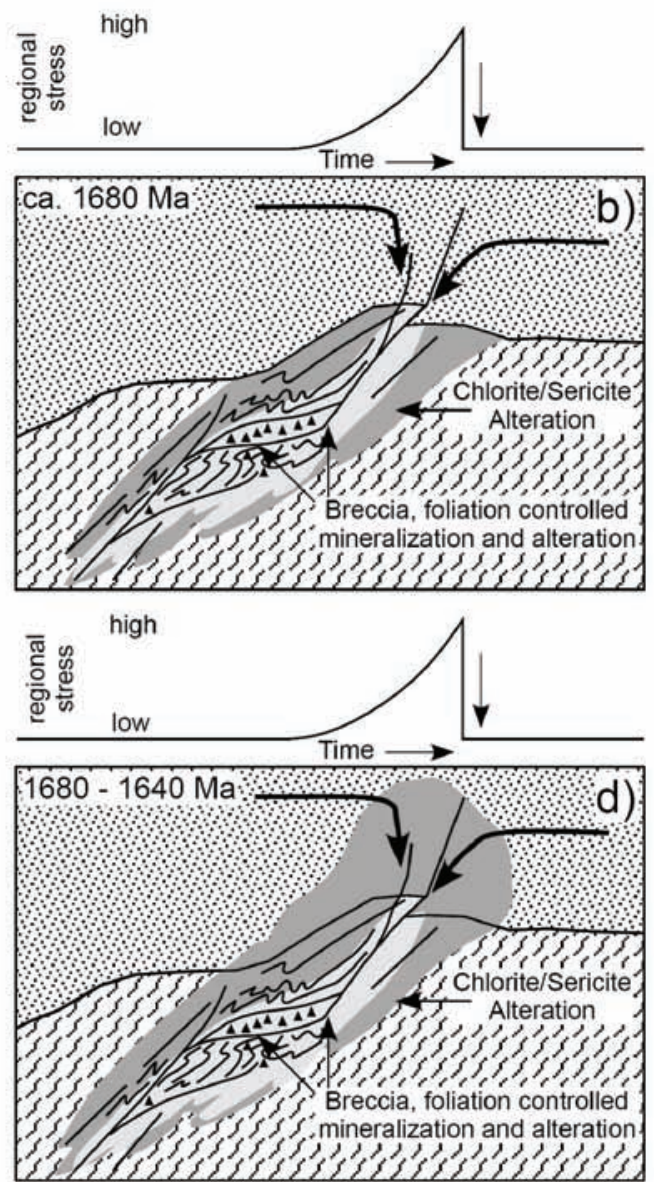

Figure 3 A schematic representation of the formation of alteration styles surrounding the Jabiluka U deposit (after Polito et al., 2005).

\section{Gold mineralisation}

Almost all Au occurrences in the Pine Creek Orogen are confined to the Central Domain (Figure 1). They are preferentially hosted by the South Alligator Group and the lower parts of the Finniss River Group along anticlines, strike-slip shear zones and thrusts proximal to the Cullen batholith. Two main mineralisation types include goldquartz veins (e.g., Pine Creek Gold Field) and Au in Fe-rich sedimentary rocks (e.g., Cosmo Howley).

The Pine Creek Gold Field is the most productive in the Pine Creek Orogen and comprises a NW-trending belt $6 \mathrm{~km}$ long and $1 \mathrm{~km}$ wide, about $0.5 \mathrm{~km}$ West of Pine Creek, adjacent to the western margin of the Pine Creek Shear Zone. It includes 15 deposits in sheared and contact-metamorphosed turbidites of the Mount Bonnie and Burrell Creek formations. From the 1870s to 2005, the goldfield produced $47.4 \mathrm{t}$ of Au (MODAT, 2011). The majority of production (23.8 $\mathrm{t}$ of Au from ore grading $2.95 \mathrm{~g} / \mathrm{t} \mathrm{Au}$ ) came from the Enterprise mine that operated from 1985-1995. Mineralisation comprises saddle reefs and, less commonly, discordant quartz veins or fault- and shear-hosted zones. Minor $\mathrm{Au}$ is disseminated in the wall rock adjacent to quartz veins. Gold is free milling or is contained in arsenopyrite.

The Cosmo Howley mine, $60 \mathrm{~km}$ NW of Pine Creek, was another major Au producer in the Pine Creek Orogen. It produced $1.05 \mathrm{t}$ of $\mathrm{Au}$ from 1879-1915, and $15.7 \mathrm{t}$ of Au from ore grading $2.04 \mathrm{~g} / \mathrm{t} \mathrm{Au}$ from 1987-1993. The remaining indicated resource for the Cosmo underground operation is stated as $5.30 \mathrm{Mt} @ 4.6 \mathrm{~g} / \mathrm{t} \mathrm{Au}$ (MODAT, 2011). Mineralisation is broadly stratabound, being hosted by greenschist-facies banded ironstone and mudstone in the Koolpin Formation (Figure 4) on the Howley Anticline. Mineral assemblages include chlorite and actinolite with minor mica, quartz, garnet, graphite and fine-grained pyrite. Free $\mathrm{Au}$ is rare and most $\mathrm{Au}$ occurs as sub- 


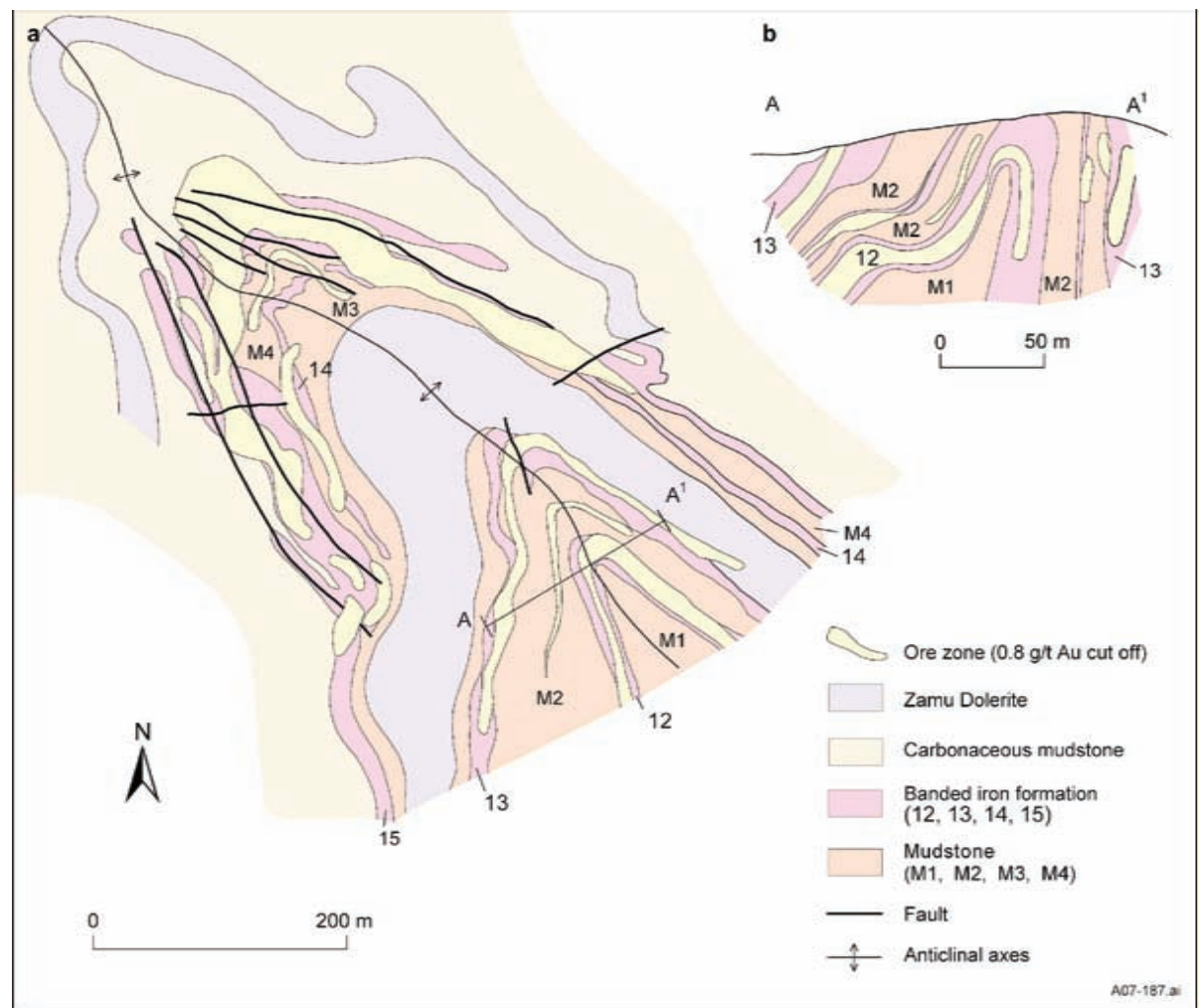

Figure 4 Geology of Cosmo Howley Au mine. a) geological plan and b) cross-section at Cosmo Howley mine (after Dominion Mining Ltd., 1998).

microscopic inclusions within arsenopyrite and pyrite. Other sulfides include minor chalcopyrite and pyrrhotite (Ahmad et al., 1999).

Gold deposits in the Pine Creek Orogen occur almost exclusively within 3-5 km of the Cullen Batholith, and are generally thought to be related to granite emplacement at 1835-1820 Ma (e.g., Matthäi et al., 1995). Goldfarb et al. (2001) included these in a distinctive class of deposits they termed 'orogenic Au deposits'. A genetic model incorporating existing observations and data was proposed by Wygralak (1996; Figure 5). However, field observations (Matthäi et al., 1995) and geochronology studies (Sener et al., 2005; Rasmussen et al., 2006) suggest that Au mineralisation at some deposits (e.g., Mount Todd and Goodall) formed 40-100 Myr after granite emplacement. This may be associated with long-lived hydrothermal systems driven by the high-heat producing granites (Rasmussen et al., 2006).

\section{Iron mineralisation}

Most known $\mathrm{Fe}$ ore occurrences in the Pine Creek Orogen are hosted by the Wildman Siltstone (Central Domain). The largest of these, the Frances Creek Iron Ore Field, was discovered in 1961 and comprises fifty named Fe ore occurrences (Figures 1 and 6). Current indicated and inferred resources (inclusive of reserves) are $8.59 \mathrm{Mt}$ @ 59.2\% Fe. The largest resources, at the Helene 5/6/7 deposit, are 5.21 Mt @ 58\% Fe. Production from September 2007-June 2010 was 4.16 Mt of ore (Territory Resources Ltd., 2010). The ore consists of massive, fine, micaceous to bladed hematite and contains varying amounts of shale fragments and quartz grains.

Crohn (1968) considered that the deposits formed as a result of supergene enrichment of pyritic shale breccia. A more recent review of mining data, along with petrological studies and field inspections of the open pits, suggested that the hematite mineralisation is the result of hydrothermal remobilisation (Bowden, 2000). Fluids derived from the intrusion of the Allamber Springs Granite concentrated Fe oxides from ferruginous banded shale in the Wildman Siltstone into pre-existing favourable structural sites. Later supergene enrichment occurred, possibly leaching phosphorus.

\section{Tectonic controls on the metallogeny in the Pine Creek Orogen}

There are strong indications that distinct tectonic settings in different parts of the Pine Creek Orogen have had an important bearing on the distribution and style of mineralisation in the orogen. Most, if not all, of these systems are related to fluid flow after, or in the late stages of, orogenesis.

Uranium deposits and occurrences are spatially linked with variably tectonised contacts with the Neoarchean basement (Figure 1), but also fall largely within the Nimbuwah Domain. These may have been

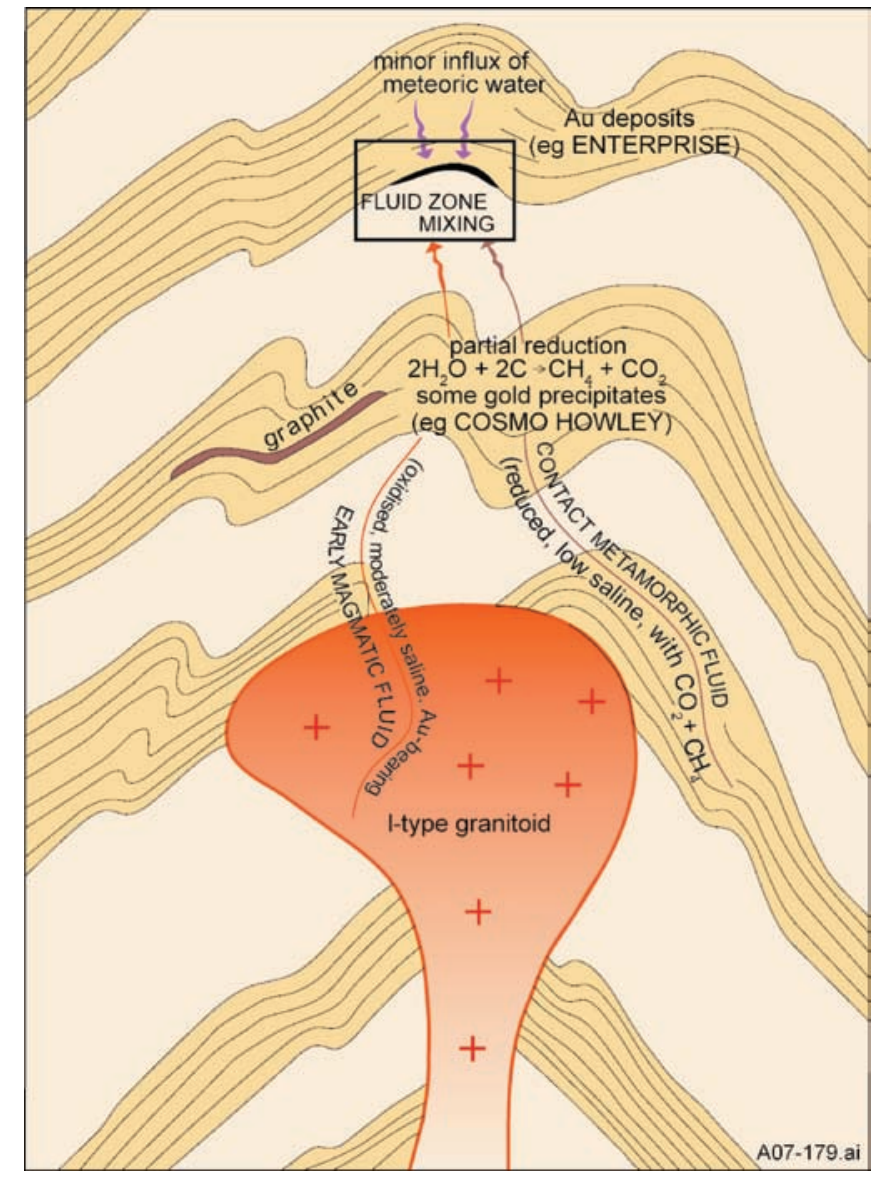

Figure 5 Model for genesis of Au deposits in the Pine Creek Orogen (after Ahmad et al., 1999). 


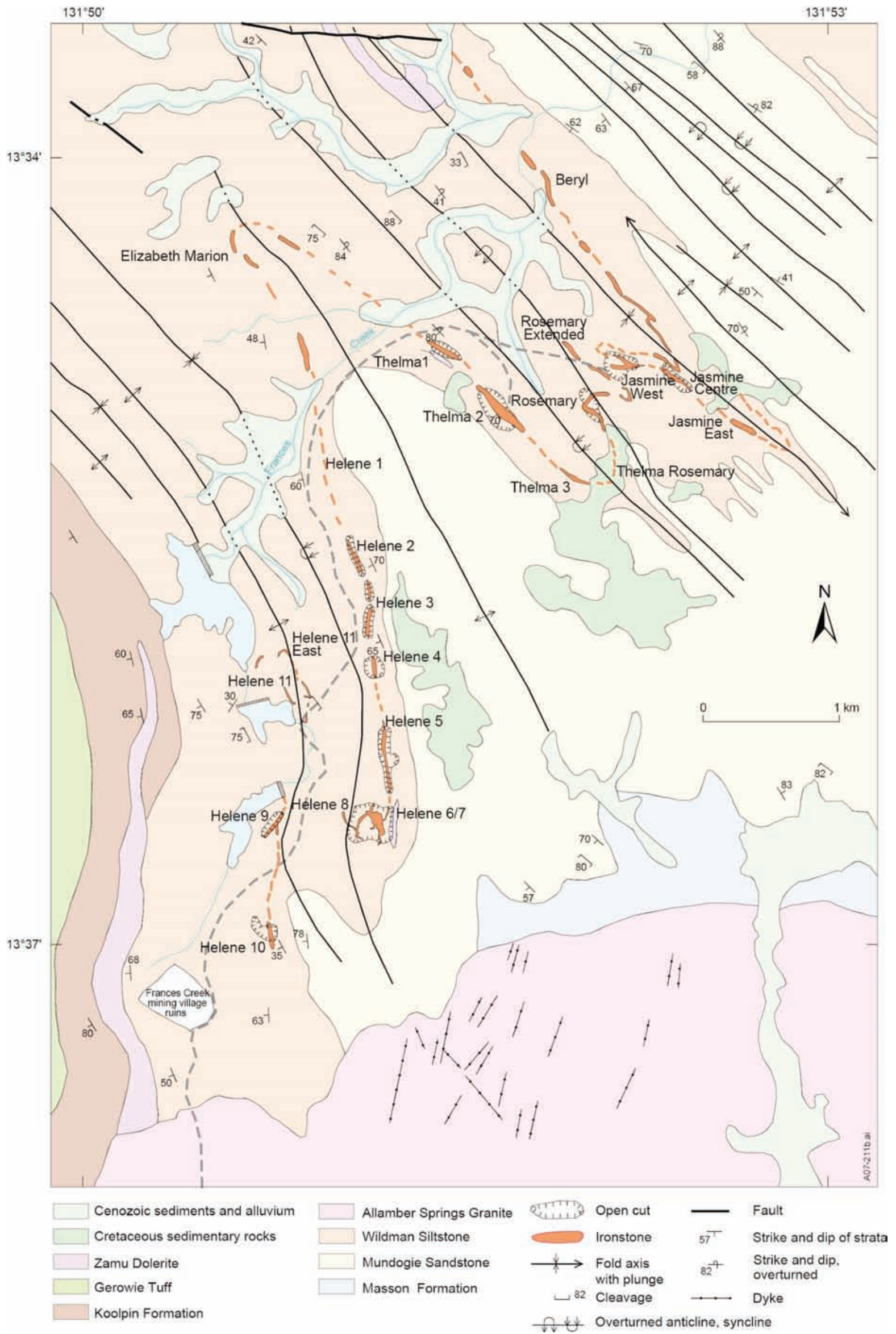

Figure 6 Geological map of southern part of Frances Creek Iron Ore Field, with significant deposits labelled (after Ferenczi, 2001). 
controlled in part by Paleoproterozoic basement structures associated with amalgamation of the Nimbuwah and Central domains at c. 1863 Ma. In the period 1867-1860 Ma, the Nimbuwah Domain experienced crustal thickening, probably in response to closure of a basin between the two domains, W-vergent thrusting, Nimbuwah Complex magmatism and associated amphibolites facies metamorphism (Hollis et al., 2009b, 2011). Subsequently, the high heat-producing granites (Neoarchean and Paleoproterozoic), coupled with the thermal cap provided by the Kombolgie Subgroup, provided the pre-existing conditions required for generation of large-scale hydrothermal systems. Reactivation of Paleoproterozoic structures may have formed important fluid conduits during subsequent Mesoproterozoic (and later) U mineralisation events. Pre-existing basement structures are known to have a strong control on $\mathrm{U}$ mineralisation at Ranger and Nabarlek.

In contrast, the Central Domain is dominated by Au deposits and occurrences, which have a strong spatial, and to some degree temporal, association with late orogenic granites. The Cosmo Supergroup, which hosts Au occurrences, is dominated by turbidites of the Finniss River Group, thought to have been deposited in a foreland basin sourcing detritus from highlands in the Nimbuwah Domain (Hollis et al., 2009b). Greenschist-facies metamorphism and associated folding and shearing during collisional tectonism generated structural trap sites. Subsequent emplacement of 1835-1820 Ma high-level late- to postorogenic granites resulted in the interaction of gold-bearing magmatic fluids with reduced, low-salinity contact-metamorphic fluids and the precipitation of $\mathrm{Au}$ in reduced lithologies in these pre-existing traps. High heat-producing granites probably also generated long-lived hydrothermal systems, accounting for Au mineralisation that significantly postdates granite emplacement. Such long-lived fluid systems are also thought to have been responsible for the $\mathrm{Fe}$ mineralisation at Frances Creek.

\section{Acknowledgements}

Steve Sheppard and Terry Mernagh are thanked for constructive reviews. Kathy Johnston (NTGS) produced high quality figures.

\section{References}

Ahmad, M, Wygralak, A.S. and Ferenczi, P.A., 1999, Gold deposits of the Northern Territory: Northern Territory Geological Survey, Report 11.

Annesley, I.R., Madore, C., Troy, A. and Hughes, L., 2002, Petrochemistry and $\mathrm{U}-\mathrm{Pb}$ monazite geochronology of granitic pegmatite from the Ranger U deposit, Australia, in Saskatoon 2002. Geological Association of Canada and Mineralogical Association of Canada Joint Annual Meeting, May 27-29: Poster and Abstract.

Bowden, S., 2000, Summary of the Frances Creek iron deposits, Northern Territory. Hamersley Iron Ltd: Northern Territory Geological Survey, Open File Company Report CR 2000-0436.

Carson, C.J., Worden, K.E., Scrimgeour, I.R. and Stern, R.A., 2008, The Palaeoproterozoic tectonic evolution of the Litchfield Province, western Pine Creek Orogen: insight from recent U-Pb zircon and in-situ monazite geochronology: Precambrian Research, v. 166, pp. 145-167.

Carson, C.J., Claoué Long, J., Stern, R.A., Close, D.F., Scrimgeour, I.R. and Glass, L.M., 2009, Summary of results. Joint NTGS-GA geochronology project: Arunta and Pine Creek regions, July 2006-May 2007: Northern Territory Geological Survey, Record 2009-001.

Carson, C.J., Hollis, J.A., Glass, L.M., Close, D.F., Whelan, J.A. and Wygralak, A., 2010, Summary of results. Joint NTGS GA geochronology project: East Arunta Region, Pine Creek Orogen and Murphy Inlier, July 2007-
June 2009: Northern Territory Geological Survey, Record 2010-004.

Crohn, P.W., 1968, The mines and mineral deposits of the Katherine-Darwin region: Bureau of Mineral Resources, Australia, Bulletin 82.

Cross, A.J., Claoué-Long, J.C., Scrimgeour, I.R., Ahmad, M. and Kruse, P.D., 2005, Summary of results. Joint NTGS GA geochronology project: Rum Jungle, basement to southern Georgina Basin and eastern Arunta Region 2001-2003: Northern Territory Geological Survey, Record 2005-006.

Dominion Mining Ltd., 1998, Annual Report to shareholders.

Etheridge, M.A., Rutland, R.W.R. and Wyborn, L.A.I., 1987, Orogenesis and tectonic process in the early to middle Proterozoic of northern Australia, in Kroner, A. (ed), Proterozoic Lithospheric Evolution: American Geophysical Union, Washington, Geodynamic Series 17, pp. 131-147.

Ferenczi, F., 2001, Iron ore, manganese and bauxite deposits of the Northern Territory: Northern Territory Geological Survey, Report 13.

Freidmann, S.J. and Grotzinger, J.P., 1994, Sedimentology, stratigraphy and tectonic implications of a paleo-Proterozoic continental extensional basin: the El Sherana-Edith River Groups, Northern Territory, Australia: Canadian Journal of Earth Sciences, v. 31, pp. 748-764.

Glass, L.M., 2010, Palaeoproterozoic island-arc-related mafic rocks of the Litchfield Province, western Pine Creek Orogen, Northern Territory: Northern Territory Geological Survey, Record 2010-005.

Glass, L.M., Hollis, J.A., Carson, C.J., Yaxley, G. and Armstrong, R., 2010, Archaean and Palaeoproterozoic crustal evolution processes in the Pine Creek Orogen: $\mathrm{U}-\mathrm{Pb}, \mathrm{Hf}, \mathrm{O}, \mathrm{Nd}$ isotopic data and geochemistry, in Annual Geoscience Exploration Seminar (AGES) 2010. Record of abstracts: Northern Territory Geological Survey, Record 2010-002.

Goldfarb, R.J., Groves, D.I. and Gardoll, S., 2001, Orogenic gold and geologic time; a global synthesis: Ore Geology Reviews, v. 18, pp. 1-75.

Hein, K.A.A., 2002, Geology of the Ranger Uranium Mine, Northern Territory, Australia: structural constrains on the timing of uranium emplacement: Ore Geology Reviews, v. 20, pp. 83-108.

Hollis, J.A., Carson, C.J. and Glass, L.M., 2009a, SHRIMP U-Pb zircon geochronological evidence for Neoarchean basement in western Arnhem Land, northern Australia: Precambrian Research, v. 174, pp. 364-380.

Hollis, J.A., Scherstén, A., Glass, L.M. and Carson, C.J., 2009b, Stratigraphic and tectonic evolution of the Nimbuwah Domain: A separate terrane to the rest of the Pine Creek Orogen? in Annual Geoscience Exploration Seminar (AGES) 2009. Record of Abstracts: Northern Territory Geological Survey, Record 2009-002.

Hollis, J.A., Glass, L.M., Carson, C.J., Armstrong, R., Yaxley, G., Kemp, A.I.S., Scherstén, A. and Phillips, D., 2011, The geological evolution of the Pine Creek Orogen: New pieces in the puzzle on orogen and craton scale, in Annual Geoscience Exploration Seminar (AGES) 2011. Record of Abstracts: Northern Territory Geological Survey, Record 2011-003.

Jagodzinski, E.A., 1998, Shrimp U-Pb dating of ignimbrites in the Pul Pul Rhyolite, Northern Territory: a cautionary tale: Australian Geological Survey Organisation, Research Newsletter 28, pp. 23-25.

Lally, J.H. and Bajwah, Z., 2006, Uranium deposits of the Northern Territory: Northern Territory Geological Survey, Report 20.

Matthäi, S.K., Henley, R.W., Rose, S.B., Binns, R.A., Andrew, A.S., Carr, G.R., French, D.H., McAndrew, J. and Kananagh, M.E., 1995, Intrusion related high temperature gold quartz veining in the Cosmopolitan Howley metasedimentary rock-hosted gold deposit, Northern Territory, Australia: Economic Geology, v. 90, pp. 1012-1045.

McAndrew, J., Williams, I.S. and Compston, W., 1985, A concealed Archaean complex in the Pine Creek Geosyncline, N.T., in CSIRO Division of Mineralogy and Geochemistry Research Review 1985: CSIRO, Melbourne, pp. 56-57.

MODAT, 2011, Mineral Occurrence Database, Northern Territory Geological Survey, Digital Information Package DIP003 (September 2011).

Needham, R.S., 1988, Geology of the Alligator Rivers Uranium Field, Northern Territory: Bureau of Mineral Resources, Australia, Bulletin 224.

Needham, R.S., Stuart-Smith, P.G. and Page, R.W., 1988, Tectonic evolution of the Pine Creek Inlier, Northern Territory: Precambrian Research, v. 40-41, pp. 543-564.

Page, R.W., 1996a, Sample 79125009 (Plum Tree Creek Volcanics): 
Geoscience Australia OZCHRON geochronology database.

Page, R.W., 1996b, Sample 792503 (Mount Bundey Granite): Geoscience Australia OZCHRON geochronology database.

Page, R.W. and Williams, I.S., 1988, Age of the Barramundi Orogeny in northern Australia by means of ion microprobe and conventional $\mathrm{U} \mathrm{Pb}$ zircon studies: Precambrian Research, v. 40-41, pp. 21-36.

Page, R.W., Compston, W. and Needham, R.S., 1980, Geochronology and evolution of the late-Archaean basement and Proterozoic rocks in the Alligator Rivers uranium field, Northern Territory, Australia, in Ferguson, J. and Goleby, A.B. (eds), Uranium in the Pine Creek Geosyncline: proceedings of the International Uranium Symposium on the Pine Creek Geosyncline: International Atomic Energy Agency, Vienna, pp. 39-68

Page, R.W., Bower, M.J. and Guy, D.B., 1985, An isotopic study of granites in the Litchfield Block, Northern Territory: BMR Journal of Australian Geology and Geophysics, v. 9, pp. 209-223.

Pietsch, B.A. and Edgoose, C.J., 1988, The stratigraphy, metamorphism and tectonics of the early Proterozoic Litchfield Province and western Pine Creek Geosyncline, Northern Territory: Precambrian Research, v. 40/41, pp. $565-588$

Polito, P.A., Kyser, T.K., Thomas, D., Marlatt, J. and Drever, G., 2005, Reevaluation of the petrogenesis of the Proterozoic Jabiluka unconformityrelated uranium deposit, Northern Territory, Australia: Mineralium Deposita, v. 40, pp. 257-288.

Polito, P.A., Kyser, T.K., Alexandre, P., Hiatt, E.E. and Stanley, C.R., 2011. Advances in understanding the Kombolgie Subgroup and unconformityrelated uranium deposits in the Alligator Rivers Uranium Field and how to explore for them using lithogeochemical principles: Australian Journal of Earth Sciences, v. 58, pp. 453-474.

Rasmussen, B., Sheppard, S. and Fletcher, I.R., 2006, Testing ore deposit models using in situ U-Pb geochronology of hydrothermal monazite: Paleoproterozoic gold mineralization in northern Australia: Geology, v. 34 , pp. $77-80$.

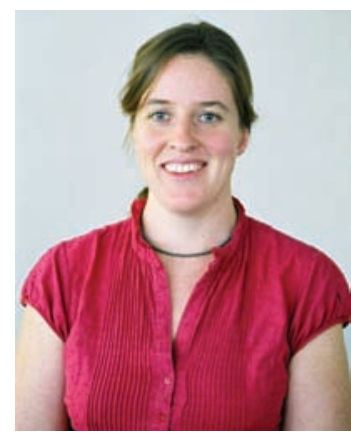

Julie Hollis is a project manager at the Geological Survey of Western Australia. Her research involves mapping, geochronology and metamorphic petrology with application to the tectonic evolution of the Kimberley region, North Australian Craton. She completed her BSC in 1996 at the University of Sydney on the metamorphic history of Cretaceous granulites from Fiordland, New Zealand and her PhD in 2000 at the University of Edinburgh on natural and experimental constraints on ultra-high temperature metamorphism.
Rawlings, D.J. and Page, R.W., 1999, Geology, geochronology and emplacement structures associated with the Jimbu Microgranite, McArthur Basin, Northern Territory: Precambrian Research, v. 94, pp. 225-250.

Sener, A.K., Young, C., Groves, D.I., Krapez, B. and Fletcher, I.R., 2005, Major orogenic gold episode associated with Cordilleran-style tectonics related to the assembly of Paleoproterozoic Australia? Geology, v. 33, pp. 225-228.

Stuart-Smith, P.G., Needham, R.S., Page, R.W. and Wyborn, L.A.I., 1993 , Geology and mineral deposits of the Cullen Mineral Field: Bureau of Mineral Resources, Australia, Bulletin 229.

Sweet, I.P., Brakel, A.T. and Carson, L., 1999, The Kombolgie Subgroup - a new look at an old 'formation': Australian Geological Survey Organisation, (AGSO), Research Newsletter, v. 30, pp. 26-28.

Territory Resources Ltd., 2010, ASX Announcement, 30/06/2010.

Williams, I.S. and Compston, W., 1983, Ion microprobe U-Pb dating of zircons from granitoids recovered in core from drill holes P4/1D, P11/1, P12/11 and P14/1, Woolner, Northern Territory, in Manning, E.R., Richardson, B.R. and Starkey, L.J., Annual Report for EL 3478 "Woolner”, Appendix 3. Mobil Energy Minerals Australia Inc: Northern Territory Department Geological Survey, Open File Company Report CR 1983-0231.

Worden, K.E., Carson, C.J., Close, D.F., Donnellan, N. and Scrimgeour, I.R., 2008a, Summary of results. Joint NTGS-GA geochronology project: Tanami Region, Arunta Region, Pine Creek Orogen and Halls Creek Orogen correlatives, January 2005-March 2007: Northern Territory Geological Survey, Record 2008-003.

Worden, K.E., Carson, C.J., Scrimgeour, I.R., Lally, J. and Doyle, N., 2008b, A revised Palaeoproterozoic chronostratigraphy for the Pine Creek Orogen, northern Australia: Evidence from SHRIMP U Pb zircon geochronology: Precambrian Research, v. 166, pp. 122-144.

Wygralak, A.S., 1996, A regional study of mesothermal, quartz vein-hosted gold deposits in the Pine Creek Geosyncline: PhD thesis, Queensland University, Brisbane (unpublished).

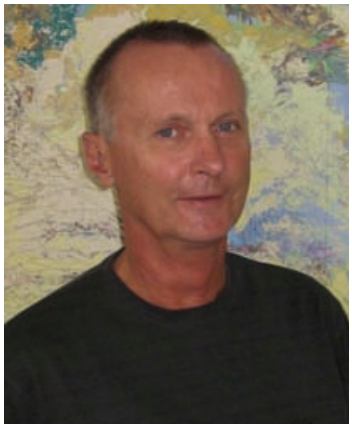

Andrew Wygralak is a qualified geologist with extensive mineral exploration experience in Australia and Poland. He has a PhD in Earth Sciences from the University of Queensland (Australia) and a MSc in Geology from the University of Warsaw (Poland). Since 1982, Andrew has been employed by the Northern Territory Geological Survey in Darwin as a mineral resource geologist. In his current position as a Senior Geologist and a Project Manager, he is responsible for geoscientific work involving provision of geoscientific data and facilitation of mineral exploration in the Northern Territory of Australia. 